\author{
Mateusz Smolarski \\ Doktorant \\ Instytut Geografii i Rozwoju Regionalnego; Wydział Nauk o Ziemi i Kształtowania \\ Środowiska; Uniwersytet Wrocławski \\ mateusz.smolarski@gmail.com
}

DOI: 10.35117/A_ENG_18_03_01

\title{
Railway border crossings on Polish-Czech borderland. Level of utilization and public transport offer
}

\begin{abstract}
Polish-Czech borderland shows similar potential for development of railway transport. Demographic, economic and tourist potentials can cause positive effects for local and regional railways. Significant elements creating international cooperation and flow of habitants are international railway connections, especially local and regional and public transport offer. Important feature is aspiration for high level of utilization border crossings. In paper author raised issues linked with permeability of border and railway service of selected cities in Polish-Czech borderland.
\end{abstract}

Keywords: Polish-Czech borderland; Railway transport; Border crossings

\section{Introduction}

Borderline research may be related to transport aspects [11] resulting from communication links and elements of border permeability assessment [5,6,7,2 p. 404-406]. As part of the research of the border area there is a shortage of research on both (or more) countries, especially in the field of comparative research. Analysis present in the literature of the subject of analysis often concern one side of the border without taking into account the differences [9, p.16]. The subject of transport and communication in borderline research (more broadly in the international aspect; [10, 7] may refer to the linear infrastructure (railway or road) [4], p. 303, 306-311; [3] p.555-556).

In the analysis, the area of the Polish-Czech border region was accepted as a research area, with particular emphasis on railway border crossings (Figure 1) It should be noted that the situation of local railway lines in both transport systems is different. In 1989-2011, 90\% of the lowest category railway lines in Poland were closed, while at the same time in the Czech Republic, only $14 \%$ of this type of lines were concerned [12]. In addition, an important element is the existence of common cross-border areas attractive for tourist ([1], p.81; [8]).

The main purpose of the analysis is to present the classification of railway border crossings and to assess the degree of their use.

The railway border crossing is an element of the linear and point infrastructure, and is an element directly affecting the permeability of the border, understood as the "physical possibility of crossing the border" [6, p.19]. There is a direct connection between the permeability of the border and the border movement and the level of formalization of the border as a barrier and transport infrastructure [Ibidem, p.20]. Formalizing the border (and its process of crossing) at the internal borders of the European Union after Poland's accession to the Schengen Agreement de facto ceased to be a barrier to passenger movements. Perhaps the lack of coordination in creating timetables by various carriers or limiting the transport offer can be considered as a difficulty. Therefore, the dependencies between the infrastructure (including the functioning of passenger connections) and the permeability of the border remained.

Therefore, this analysis will mainly concern the degree of use of railway border crossings and the assessment of the possibility of crossing the border into the abovementioned border crossing points. The research methods are based mainly on the analysis of documents 
(including railway infrastructure managers and railway carriers), the query of network timetables and cartographic documents.

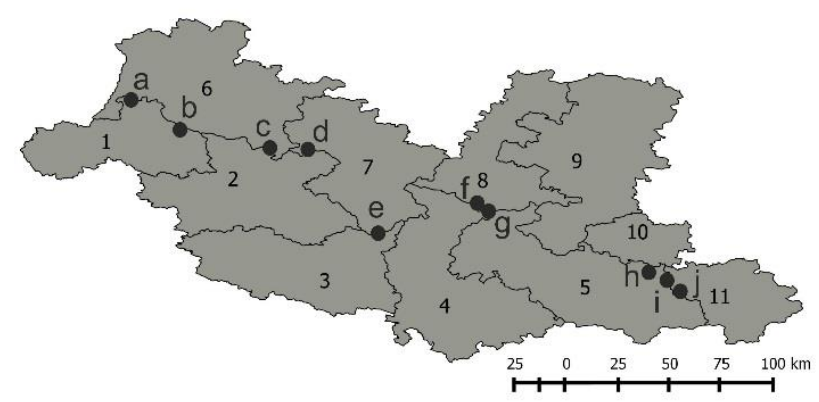

1. The analysis area together with active railway passages (letter designations of transitions in the tab.1)

Tab.1 Open railway crossings on the Polish-Czech border

\begin{tabular}{|lllll|l|}
\hline Border crossing & Category & Characteristics & $\begin{array}{l}\text { Number of cross- } \\
\text { border connections }\end{array}$ \\
\hline \hline Zawidów (a) & Visnova & Freight & $\begin{array}{l}\text { open without passenger } \\
\text { traffic }\end{array}$ & none \\
\hline $\begin{array}{l}\text { Szklarska Poręba } \\
\text { (b) }\end{array}$ & Harrachov & Passenger & $\begin{array}{l}\text { open with passenger } \\
\text { traffic }\end{array}$ & 8 \\
\hline Kamienna Góra (c) & Kralovec & Season & $\begin{array}{l}\text { open with seasonal } \\
\text { passenger traffic }\end{array}$ & 4 \\
\hline Mieroszów (d) & Mezimesti & Freight & $\begin{array}{l}\text { open without passenger } \\
\text { traffic }\end{array}$ & none \\
\hline Międzylesie (e) & Lichkov & $\begin{array}{l}\text { Passenger } \\
\text { and freight }\end{array}$ & $\begin{array}{l}\text { open with passenger } \\
\text { traffic }\end{array}$ & 4 \\
\hline Głuchołazy (f) & Mikulovice & Transit & $\begin{array}{l}\text { open with passenger } \\
\text { traffic }\end{array}$ & 4 \\
\hline Głuchołazy (g) & Jindrichov & ve & $\begin{array}{l}\text { open with passenger } \\
\text { Trnsit }\end{array}$ & 4 \\
\hline Chałfic & Blezsupki (h) & Bohumin & $\begin{array}{l}\text { Passenger } \\
\text { and freight }\end{array}$ & $\begin{array}{l}\text { open with passenger } \\
\text { traffic }\end{array}$ & 4 \\
\hline Zebrzydowice (i) & Petrovice u Karvine & $\begin{array}{l}\text { Passenger } \\
\text { and freight }\end{array}$ & $\begin{array}{l}\text { open with passenger } \\
\text { traffic }\end{array}$ & $\begin{array}{l}\text { No stops } \\
\text { express connections) }\end{array}$ \\
\hline Cieszyn (j) & Cesky Tesin & $\begin{array}{l}\text { Passenger } \\
\text { and freight }\end{array}$ & $\begin{array}{l}\text { open with passenger } \\
\text { traffic }\end{array}$ & 6 \\
\hline
\end{tabular}

Own study based on data from PKP PLK and carriers. Letter designations refer to Fig.1

\section{Railway border crossing}

Border crossings constitute a point element of the transport infrastructure by means of which it is possible to cross the state border. After Poland entered the Schengen area (2007/2008) crossing the border by pedestrians is practically possible on the whole length. In the case of bus and rail transport, border crossing infrastructure is still used. It should be noted, however, 
that the infrastructure at the border has been very limited (eg the lack of customs and passport control stations, the suspension of the existence of Border Guard posts, etc.). In domestic and international terms, the degree of use of border sections is important. In 1994, out of 8 active cross-border railway lines, four are used in passenger traffic [ 7 p.24] (according to Komornicki, the use of railway lines in later years fell to 41.7\%). On the most-used Polishgerman border in the period of above-mentioned research for the same number of railway lines, 5 are used [7, p.24]. Based on the analysis of railway crossings on the Polish-Czech border (Fig. 1, Table 1), the utilization rate was assessed at a high level: $80 \%$. This means that on 10 rail crossings, passenger traffic is carried out on eight, including only seasonal passenger traffic (Lubawka-Kralovec) on a single pass. In addition, the passage Zebrzydowice-Petrovice despite technical capabilities is not supported by passenger trains (regional), only through fast connections and higher categories not performing commercial stops in Zebrzydowice and Petrovice. The largest number of cross-border connections is carried out at the Szklarska Poręba-Harrachov and Cieszyn-Czeski Cieszyn crossings, where respectively on average 8 and 6 connection pairs are performed during the working day. At the other border points, the number of connections oscillates at the level of 4 per day (on average, 4.85 cross-border train rates are performed per working day), which, given the proper timetable structure, seems to be an appropriate offer. One should pay attention to the discrepancy of the communication offer, which on the local railway lines (e.g. Szklarska Poręba) can be more developed than on the main international lines (e.g. MiędzylesieLichkov). In addition, there is diversity in the hierarchy of railway border crossings, because only three of them (Zebrzydowice-Petrovice, Chałupki-Bohumin, and Międzylesie-Lichkov) have long-distance routes and two (Zebrzydowice-Petrovice and Chałupki-Bohumin) connections with a higher category (express). All other border points can be considered as transitions with strictly regional status. Such typology is a kind of simplification, because the option of changing between border stations and the transport offer is not taken into account. Nevertheless, it is a possibility of diversifying the qualifications of border crossings. Głuchołazy, which serves as a transit station for Czech connections to Krnov and Jesenik, is interesting in terms of communication offer and transport organization. Transit trains carry out a commercial stop at the station in Głuchołazy, where the front of the train is changed. Interestingly, in the current timetable $(2015 / 16)$ with 8 pairs of connections on business days running in the direction of the Czech Republic, there are no courses in the direction of Nysa.

\section{Inactive lines divided by the border}

In addition to the above-mentioned lines, the existence of historical cross-border railway lines (Fig.2) should be noted, which after 1945 became less important and passenger traffic was gradually extinguished, or after military operations, the railway infrastructure was demolished (out of 78 all railway lines crossing the borders) Poland and neighbors thirty-four were closed in 1945 [7, p.16]). In the area of Ziemia Kłodzka, because of the Polish-Czechoslovak conflict, the so-called preventive closure of railway lines was used. It was aimed at limiting possible movements of Czechoslovak troops towards Poland. This concerned, among others railway line in the vicinity of Ścinawka (section: Tłumaczów- Otovice). In the studied area, 8 lines of this type were identified: Tłumaczów- Otovice; Krzanowice-Chuchelna; PilszczKaterinky; Pietrowice Wielkie- Krnov; Kałków Łąka - Vidnava; Dziewiętlice - Bernartice at Javornik; Mirsk-Pobiedna. In addition to the above there were also connections between Kudowa Zdrój and Nachod, which were used sporadically in 1945-48. The most important sections for possible international traffic (i.e. cross-border sections) were mostly dismantled in 1945. They were local railway lines and it seems that their actions in the face of later liquidation of local connections would also be in doubt. 


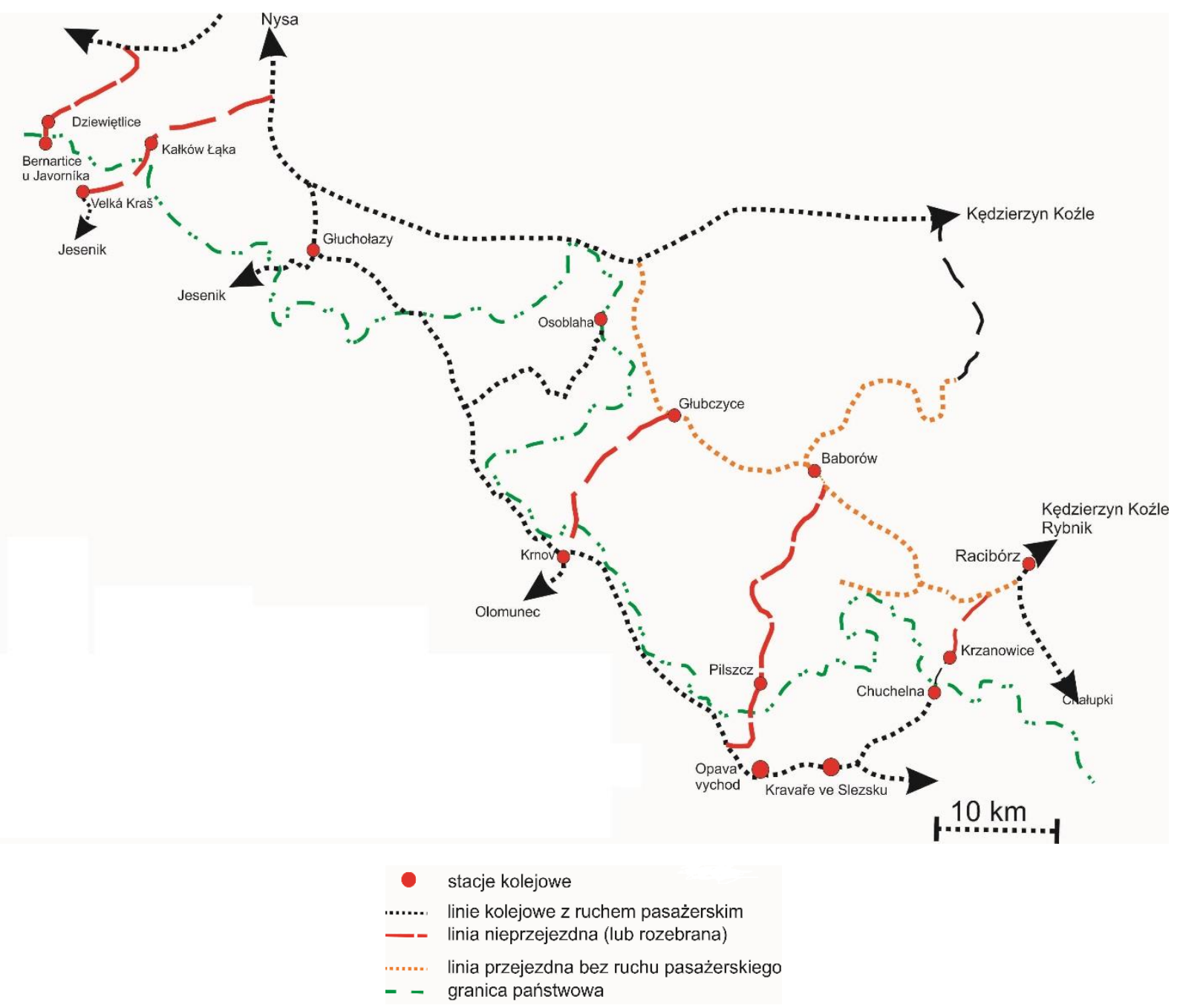

2. Railway lines cut by the border after 1945 (own work)

\section{Border cities}

A very important issue was the above-mentioned processes of physical liquidation of railway routes. While on the Polish side such a process was relatively frequent, on the Czech side the first railway station behind the border line still performs its communication functions. This is one of many examples illustrating the completely different approach of decision makers to transport systems in both countries. On seven analyzed railway lines, in three cases, border cities (at the same time Polish and Czech) are deprived of passenger rail (Table 2). The remaining four railway lines are characterized by the functioning of rail transport in Czech cities with the simultaneous lack of railway connections on the Polish side. Railway lines on the Polish side usually had a gradually reduced passenger transport offer, until its complete withdrawal, resulting in the lack of connections at all border railway stations on "broken" railway lines. One of the more distinct examples of differences in the discussed area is the pair of the village of Pietrowice Głubczyckie-Krnov, where on the Polish side the traffic was suspended in the 1970s (passenger), and on the Czech side in Krnov daily 41 passenger trains are sent off. Differences between Dziewiętlice and Bernartic u Javornik and Krzanowice and Chuchelna are equally marked. The suspension of traffic on the mentioned lines was in line with the general trend of closing the lowest category lines in Poland [12, p.128].

The assessment of railway transport in cities located on the Polish-Czech border can be made for urban centers located near active border crossings (Fig. 3). The analysis covered 10 border crossings (19 cities). The most distinctive feature is the lack of passenger rail 
connections in three Polish cities (Lubawka, Mieroszów, and Zawidów) and the presence of only one city deprived of rail transport in the Czech Republic (Kralovec, only on certain dates). The specific location of the station on the Polish side may be an important element influencing such disproportion in the scope of railway service. These are stations on local, non-electrified railway lines, in peripheral areas. For the first stations on the other side of the border (for Mieroszów it is Mezimesti and for Zawidów - Visnov), the high number of passenger connections is highlighted during the day. In the case of Mezimesti, there are 33 courses per day (Visnova 17). In most cases, these are regional courses to the nearest major node stations. All discussed city pairs are characterized by a greater number of courses on the Czech side, the exception is the pair Zebrzydowice - Petrovice u Karvine and Szklarska Poręba- Harrachov (in this case the number of connections is the same). It may be influenced by the fact that only regional trains stop at the Czech station in Petrovice. A pair of CieszynCzech Cieszyn cities, according to the author, is the best example of diversifying rail transport in both countries. The potential of both railway stations is at a similar level, which is influenced by their location in the border city. However, this does not turn into the offer of rail transport; 12 connections in Cieszyn daily, and 139 connections in Czech Cieszyn in the same period. What is important these are not only regional but also long-distance courses (including Prague, Ostrava). On the Polish side (apart from cross-border trains), the transport offer is only made to Zebrzydowice and Czechowice Dziedzic. One of the manifestations of transport marginalization was the suspension of traffic on the railway line No. 190 (Bielsko Biała Główna - Czech Cieszyn), which enabled a quick connection with the station in Bielsko-Biała. Similarly, the high disproportion is noticeable for the Chałupki-Bohumin couple (13 and 107 connections respectively). High-speed and express trains stop in Chałupki. It should be noted that the location of Bohumin and Czech Cieszyn on one of the major Czech railways undoubtedly influences their communication rank, but nevertheless, the level of disproportion in the number of connections definitely shows the diversity of both public transport systems.

Tab.2 Transport offer of border cities (closed railway crossings)

\begin{tabular}{|ll|}
\hline City & $\begin{array}{l}\text { Average number of } \\
\text { railway connections }\end{array}$ \\
\hline \hline Otovice & 0 \\
Tłumaczów & 0 \\
\hline Krzanowice & 0 \\
Chuchelna & 19 \\
\hline Pilszcz & 0 \\
Katerinky & 0 \\
\hline Pietrowice Głubczyckie & 0 \\
Krnov & 41 \\
\hline Kałków Łąka & 0 \\
Vidnava & 0 \\
\hline Dziewiętlice & 0 \\
Bernartice u Javornika & 26 \\
\hline Pobiedna & 0 \\
Jindrichovice pod Smrekiem & 3 \\
\hline
\end{tabular}

Own work 


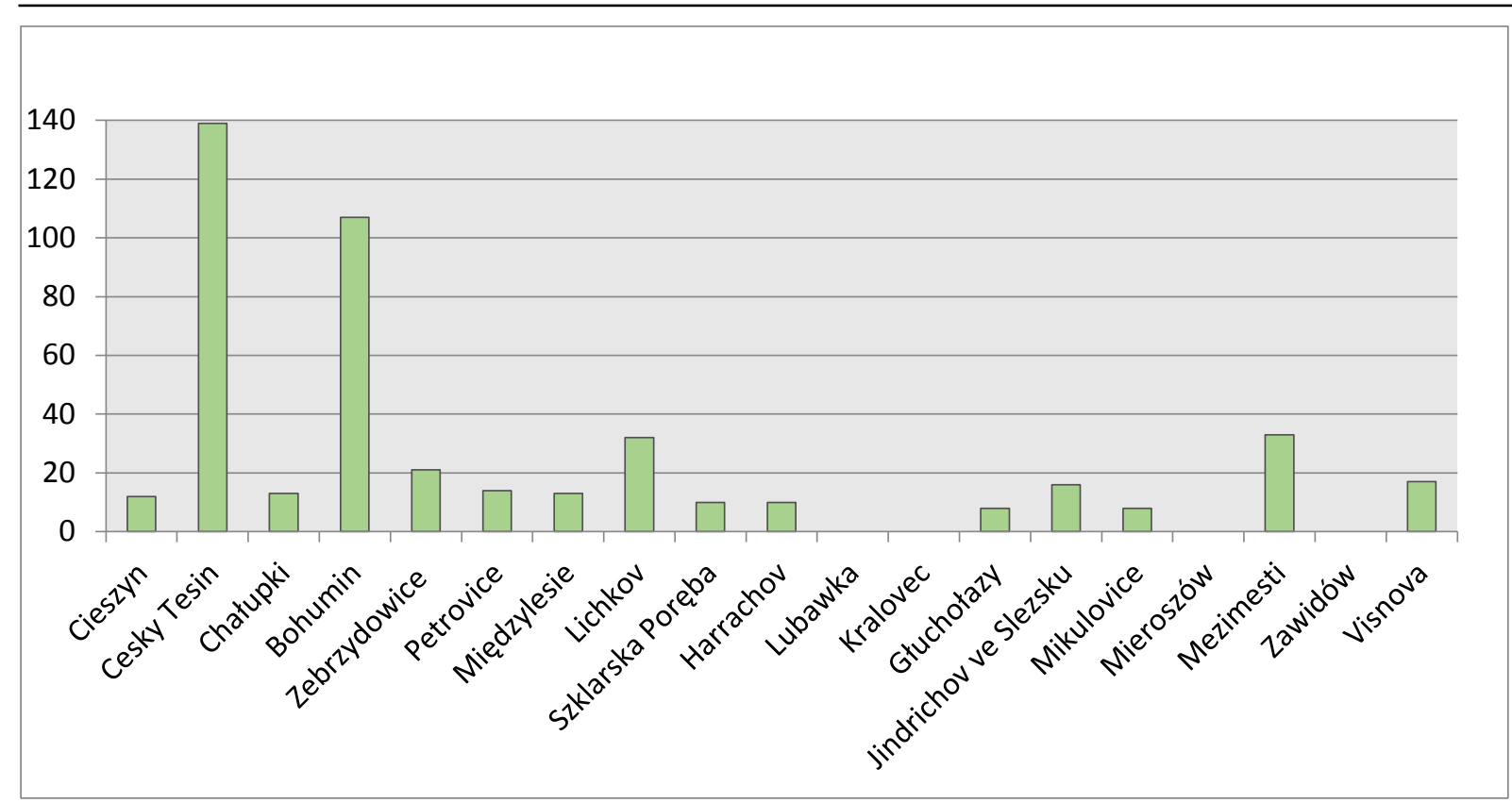

3. Transport offer of border cities (active railway crossings) (own work))

\section{Conclusions}

The level of utilization of cross-border rail lines in passenger traffic at the level of $33 \%$ in 1994 increased to almost $80 \%$ (in relation to passable cross-border lines). In the following years, on the one hand, the index should be increased (by opening next border crossings for passenger traffic, e.g. in 2017, the reactivation of connections between Wałbrzych and Mieroszów is planned), and on the other hand, construct an appropriate offer of cross-border connections. Their role can be assessed in two ways: as cross-border local-regional (e.g. Cieszyn-Czech Cieszyn, Lubawka-Trutnov) and cross-border trans-regional, which after crossing the border allow larger interchanges to continue their journey into the country. It is necessary to avoid the traffic situation only to the first station, borderline, from which often any further journey is difficult or impossible [7,p.37]. According to the author of this analysis, any assessment of the functioning of border crossings (and more broadly railway lines) should begin with the evaluation of the timetable and the system of tariffs and transfers. Lack of appropriate demand for using regional and local rail services is too often mistakenly identified with a voluntary choice of potential passengers (and not a poorly constructed transport offer), which in turn may lead to premature traffic suspension.

On the other hand, the assessment of peripheral cities located on cross-border railway lines (active and interrupted after 1945 by the border) made it possible to capture the developmental differences in the transport services of urban centers. The discontinuation of many railway lines after 1945 decided on a similar potential for the development of local transport in Poland and the Czech Republic. However, the current offer of railway transport is in many cases completely different. The very fact that on 7 interrupted railway lines all the border cities located on the Polish side are deprived of rail transport allows drawing attention to spatial diversity. Similar differences are noticeable in the assessment of cities located on cross-border active lines. Apart from the use of border crossing capacity, in most cases a high degree of differentiation is evident. According to the author, this is best illustrated by border towns, Cieszyn-Czech Cieszyn, where nearly 12 times more passenger trains depart from the Czech station per day than from Cieszyn. In the Czech passenger rail system, the fact of locating cities on the periphery of the state does not automatically mean transport and communication marginalization. 


\section{Source materials}

[1] Adamczuk F., Przestrzenne i organizacyjne aspekty rozwoju pogranicza polskoczeskiego, Prace Naukowe Uniwersytetu Ekonomicznego we Wrocławiu, $2015 \mathrm{nr}$. 407, s.76-85.

[2] Anisiewicz R., Transport kolejowy w Obwodzie Kaliningradzkim jako czynnik rozwoju współpracy transgranicznej; Nauki Geograficzne w Badaniach Regionalnych, 2007 t. II, s. 401-407.

[3] Brdulak J., Pawlak P., Polska Wschodnia. Infrastrukturalne pogranicze czy peryferie?, Logistyka-nauka, 2015, 3, s. 550-557.

[4] Fedan R., , Infrastruktura transportowa i graniczna- warunkiem efektywnej współpracy transgranicznej, [w:] Woźniak M.G (red.) Spójność społecznoekonomiczna a modernizacja regionów transgranicznych, Rzeszów, 2008, s.302-312.

[5] Komornicki T., Transgraniczna infrastruktura transportowa Polski, Przegląd Geograficzny, 1994 t. LXVII, z.1-2, s.45-53.

[6] Komornicki T., Granice Polski. Analiza zmian przenikalności w latach 1990-1996, Geopolitical studies, Instytut Geografii i Przestrzennego Zagospodarowania PAN, tom $5,1999$.

[7] Lijewski T., Infrastruktura komunikacyjna Polski wobec zmian politycznych i gospodarczych w Europie Środkowej i Wschodniej, Zeszyty Instytutu geografii i przestrzennego zagospodarowania PAN, 1994, nr. 23.

[8] Potocki J., Funkcje turystyki w kształtowaniu transgranicznego regionu górskiego Sudetów, Wrocławskie Towarzystwo Naukowe, 2009.

[9] Raczyk A., Dołzbłasz S., Leśniak-Johann M., Relacje współpracy i konkurencji na pograniczu polsko-niemieckim, Gaskor, 2012.

[10]Rosik P., Dostępność lądowa przestrzeni Polski w wymiarze europejskim, Instytut geografii i przestrzennego zagospodarowania PAN, Prace Geograficzne, tom 233, 2012.

[11] Soczówka A., Dostępność komunikacji miejskiej i podmiejskiej w kraju MorawskoŚląskim w Republice Czeskiej, Acta Geographica Silesiana, 2013, 14, s.87-100.

[12] Taczanowski J.,A comparative study of local railway networks in Poland and the Czech Republic; Bulletin of Geography. Socio-economic Series, 2012, no. 18, pp.125138. 